\title{
Implementation of Criminal in Replacement Fine in Criminal Acts of Corruption
}

\author{
Vincentius Erick Mere ${ }^{1}$, Faisal Santiago ${ }^{2}$ \\ Student at Doctoral of Law, Universitas Borobudur, Jakarta Indonesia ${ }^{1,2}$ \\ \{erickmere19@gmail.com¹, faisalsantiago@borobudur.ac.id²\}
}

\begin{abstract}
Corruption is an extra ordinary crime that damages the government structure and image of the country in the eyes of the world as well as losses to the state finances or the state economy and hinders national development. The focus of the formulation of the problem of this research: whether the penalty in lieu of fines in the crime of corruption has fulfilled the return of state financial losses and a sense of justice for the sake of law. The results of the research findings in a corruption case decision, judges in imposing fines apply a subsidiary in lieu of fines in the form of imprisonment, as in the Medan District Court Decision Number 68 / Pid.Sus-TPK/2017/PN Mdn, Imposes the convicted person to a fine of IDR 50,000,000 (fifty million rupiah) provided that if the fine is not paid, it must be replaced by imprisonment for 1 (one) month each. It does not rule out the convicts will choose a penalty in lieu of a fine, namely 1 month imprisonment, this is not fulfilling the goal of the state in restoring state finances and justice for the sake of law. It's necessary to have legal certainty related to penalties in lieu of fines and more precise reformulation by taking the convict's assets from the proceeds of corruption.
\end{abstract}

Keywords: Criminal Substitution Fines; Corruption Crime

\section{Introduction}

Corruption is part of the state's problems that must be eradicated, because the criminal act of corruption is an extra ordinary crime that damages the government structure and the image of the country in the eyes of the world as well as losses to the state finances or the state economy and hinders national development, if there are many officials in the community. corruptors, so that it must be eradicated in order to create a just and prosperous society based on Pancasila and the 1945 Constitution. The form of crime that is currently being discussed is white collar crime which usually consists of respectable people or people who have power or important positions in government, such as high state officials, government bureaucracy, and politicians and even law enforcers and many more in other government agencies. Corruption is a crime that can be said to be at its lowest point and has taken root.

Corruption is a part of special criminal law. If explained, the criminal act of corruption is a specific specification that is different from general criminal law, such as irregularities in the procedural law and regulated material, which are intended to minimize leakage and irregularities in the country's finances and economy. The United Nations Convention Against 
Corruption 2003 (United Nations Convention Against Corruption (UNCAC), 2003 described "the problem of corruption is already a serious threat to the stability, security of national and international societies, it has weakened institutions, democratic values and justice, and endanger sustainable development and law enforcement ".

The Indonesian government in its efforts to handle or eradicate corruption is very serious, this is evidenced by changes in the laws and regulations on corruption, including Law Number 3 of 1971 concerning the Eradication of Corruption Crime is no longer in accordance with development of legal needs in society, therefore replaced by Law Number 31 of 1999 concerning Eradication of Corruption, which was amended to Law Number 20 of 2001 concerning Amendments to Law Number 31 of 1999, is expected to be more effective in preventing and eradicating acts of corruption. corruption crime. Even today, in terms of handling it has been specially formed, namely the Corruption Eradication Commission which is independent with the task and authority to eradicate corruption, namely the issuance of Law Number 30 of 2002 concerning the Corruption Eradication Commission.

The efforts made by the government through these laws are felt to have not been optimal, because they still provide room for different interpretations, legal loopholes, inaccurate imposing sanctions, especially in relation to the problem of implementing criminal penalties as regulated in Law Number 202001 in conjunction with Law Number 31 of 1999 concerning Eradication of Corruption Crime. In order to achieve a more effective goal of preventing and eradicating the criminal act of corruption, the Corruption Act contains provisions on the specific minimum punishment, higher fines, and the death penalty which constitutes criminal extortion.

Regarding the principal penalty, the judge in giving a decision often provides a subsidiary penalty in lieu of fines in the form of imprisonment, as one example: "Criminal cases of corruption committed by the defendants which caused losses to state finances cq. Regional Finance of Pakpak Bharat Regency, in this case the Pakpak Bharat Regency Government, is Rp. 471,945,000,- (four hundred and seventy one million nine hundred and forty five thousand rupiah), or at least the amount of Rp. 220,000,000,- (Two hundred and twenty million rupiah).

The Panel of Judges at the Medan District Court Decision Number 68 / Pid.Sus-TPK / 2017 / PN Mdn, dated November 14, 2017 Sentenced the Defendants: Sahitar Berutu, S. Ag. MA (Defendant I) - Drs. Daulat Merhukum Solin (Defendant II) - Sahrun Kudadiri, S.Pdl (Defendant III) - Ren Haney Manik, A.Md (Defendant IV) with imprisonment for 1 (one) year and 6 (six) months each and a fine. -Each IDR 50,000,000 (fifty million rupiahs) provided that if the fine is not paid it must be replaced by imprisonment for 1 (one) month each ".

The application of the main criminal sanctions imposed on the convicted corruptors is not the same as the money that was corrupted. Besides, the criminal value of the fine is $\mathrm{Rp}$. 50.0000 .000 , - is considered not comparable to a subsidiary sentence of one month imprisonment, so it does not rule out the possibility that the convicted person prefers a penalty in lieu of a fine of only 1 month imprisonment compared to paying a fine of Rp. 50,000,000, - . However, legislators have never taken into account how the execution process of unpaid fines which are replaced by imprisonment which is considered too light, so that this disturbs the effectiveness of the application of the fine itself. This is a state problem in recovering state financial losses that are not fulfilled and do not provide justice for the law itself. It's necessary to be effective in the application of these fines.

\section{Problems}


The formulation of this research is "Has the punishment in lieu of fines in the crime of corruption have been fulfilled the return of state financial losses and a sense of justice for the sake of the law?

\section{Literature Review}

\subsection{Corruption Crime}

Legal experts provide a very varied definition of corruption, including: Andi Hamzah, stated that: "Corruption is a term from Latin, which is corruptio or corruptus, which when translated literally means spoilage, ugliness, depravity, dishonesty, can be bribed, immoral, deviates from purity, slanderous words or words. Although the word corruptio has a broad meaning, it is often interpreted as bribery. The term corruption is summed up in Indonesian by Purwadarminta in the General Indonesian Dictionary. "Corruption is a bad act such as embezzlement of money, receiving bribes and so on".

Meanwhile, according to J.S. Nye in Martimah Prodjohamidjojo, states that: "Corruption is a behavior that deviates from the normal obligations of a government agency role, due to personal interests (family, class, friends, friends), to pursue status and prestige, or to violate regulations by committing or seeking influence for personal gain ". So literally it can be concluded that the term corruption actually has a very broad meaning, which in essence is that corruption is an act of embezzling or embezzling state or company money and so on for personal and other people's interests. Corruption can also be interpreted as a rotten act, damaged or using goods or money entrusted to him, can be bribed through his power for personal gain. The formulations of the definition of corruption above have provided a lot of input in the formulation of the criminal act of corruption, resulting in sanctions the law can be threatened and stipulated in tackling corruption. Corruption involves moral aspects, rotten nature and conditions, positions in government agencies or apparatus; abuse of power in office due to giving, economic and political factors, as well as the placement of families and groups into service under the power of their office.

\subsection{Elements of Corruption Crime}

The elements of the criminal act of corruption, cannot be separated from the elements contained in Article 2 and Article 3 of Law Number 31 Year 1999 concerning the Eradication of Corruption Crime, namely: Article 2 paragraph (1) of Law Number 31 Year 1999 concerning Eradication of Corruption Crimes, states that: "Every person who unlawfully commits an act of enrichment of himself or another person or a corporation that can harm the state finances or the economy of the country, will be sentenced to imprisonment for life or imprisonment for a minimum of 4 (four) years and a maximum of 20 (twenty). year and a fine of at least Rp. 200,000,000.00 (two hundred million rupiah) and a maximum of Rp. $1,000,000,000.00$ (one billion rupiah) ".

According to Firman Wijaya, if we pay attention to the elements of offense in Article 2 of Law Number 31 of 1999 concerning Eradication of Corruption, among others: (1) Against the law; (2) Actions to enrich oneself or another person or a corporation; (3) Which can be detrimental to state finances or the country's economy. To clarify the understanding of the elements contained in Article 2 of Law Number 31 of 1999 concerning the Eradication of Corruption, it is contained in Article 3 of Law Number 31 of 1999 concerning Eradication of 
Corruption Crimes. The abuse of authority contained in Article Law Number 31 of 1999 concerning Eradication of Corruption Crimes is a core offense (Bestanddell delict). The offense of abuse of authority in criminal acts of corruption is regulated in Article 3 of Law Number 31 of 1999 concerning Eradication of Corruption, which is formulated as follows:

"Anyone who, with the aim of benefiting himself or another person or a corporation, misuses his / her authority, opportunity or means due to his position or position which may cause loss to the state finances or the state economy, shall be punished with life imprisonment or imprisonment of at least 1 one) year and a maximum of 20 (twenty) years and or a fine of at least Rp. 50,000,000.00 (fifty million rupiah) and a maximum of Rp. 1,000,000,000.00 (one billion rupiah) ".

If we pay attention to the elements of offenses in Article 3 of Law Number 31 of 1999 concerning Eradication of Corruption, it can be concluded as follows: (1) With the aim of benefiting yourself or other people or a corporation; (2) Misusing the authority, opportunity, or means available to him because of his position or position; (3) Which can be detrimental to state finances or the country's economy.

To clarify the understanding relating to the elements of offense in Article 3 of Law Number 31 Year 1999 concerning the Eradication of Corruption Crimes, each of these elements can be specified:

Element: With the aim of benefiting yourself or another person or a corporation, the purpose of that action is to benefit yourself or another person or a corporation. Profitable means increasing wealth or property. The subjective element inherent in the mind of the maker according to Article 3 of Law Number 31 of 1999 concerning the Eradication of Corruption Crime is the intention of the maker in committing acts of abusing the authority, opportunity or means available to him because of his answer or position, namely to benefit himself or another person or a corporation.

Elements with the aim of benefiting themselves or others or a corporation according to Andi Hamzah stated that: "Intentional level I (intentionally as an intent or opzet met oog brand). Unlike the case with Article 2 of Law Number 31 Year 1999 concerning Eradication of Corruption Crime which with the phrase "enrich oneself, other people, or a corporation."

According to Firman Wijaya, deliberately in 3 (three) forms, namely: (1) Deliberate purpose or purpose; (2) Intentional with certainty or necessity; (3) Deliberate with possibility (Dolus Eventualis).

Element: Misusing authority, opportunity or means available to it because of position or position. The act that is committed is to abuse the authority, opportunity or means available to it because the position or position of authority means power or rights. So what is being blamed is the power or rights that are in the perpetrator. For example, to benefit their own children, siblings, grandchildren or cronies. Misusing an opportunity means misusing the time available to him in that position or position. Meanwhile, abusing the means means abusing the tools or equipment available to him because of his position or position.

Elements: Can be detrimental to state finances or the country's economy. In the provisions of Article 4 of Law Number 31 of 1999 concerning Eradication of Corruption Crime, which is stated as follows: "The return of state financial losses or the state economy does not eliminate the conviction of the criminal offender as referred to in Article 2 and Article 3". The consequence of the offense is formally considered to be the act, not the result as in the formulation of the material offense. In formal offenses, there is no need to look for a causal relationship (conditio sine quanon) between the result and the action, the most important thing is that the act is against the law or not. 
The definition of state finance can also be found in Article 1 of Law Number 17 of 2003 concerning State Finance, which is stated as follows: "State finances are all rights and obligations of the state that can be valued in money, as well as everything, whether in the form of money or in the form of goods that are made the property of the state in connection with the implementation of these rights and obligations ".

Furthermore, Article 2 of Law Number 17 of 2003 states that state finances include:

a. the right of the state to collect taxes, issue and circulate money, and make loans;

b. State obligations to carry out state government public service tasks and pay third party bills;

c. state revenue;

d. state expenditure;

e. reception area;

f. regional expenditure;

g. State assets or regional assets managed by themselves or by other parties in the form of money, securities, accounts receivable, goods, and other rights that can be valued in money, including assets separated from state or regional enterprises; The assets of other parties controlled by the government in the context of carrying out government tasks and / or public interests; Wealth of other parties obtained by using facilities provided by the government.

From the two laws, it appears that the definition of state finances in Law Number 17 of 2003 concerning State Finance is more detailed than Law Number 31 of 1999 concerning Corruption Eradication.

\subsection{Criminal Fines}

In the provisions of Article 10 of the Criminal Code, fines in the main criminal group are the last or fourth order. The sequence of Article 10 of the Criminal Code (KUHP) is:

Criminal consists of:

a. principal criminal: death penalty; imprisonment; criminal cage; criminal fine; and criminal closure.

b. additional penalties: (1) revocation of certain rights; (2) confiscation of certain goods; (3) announcement of the judge's decision.

Penalties in the Criminal Code only serve as alternative crimes or are imposed on light offenses, in the form of offenses or minor crimes. However, in current legal developments, fines can be applied cumulatively as a weighting and applied to special crimes, one of which is corruption as stated in Law Number 20 of 2001 in conjunction with Law Number 31 of 1999 concerning Eradication of Corruption. Fines contain economic value that is not owned by imprisonment. By prioritizing fines rather than imprisonment, especially the maximization of state assets, wealth is described in terms of economics and not simple monetary calculations. According to Niniek Suparni, stated that: "The imprisonment of a fine must be paid by the convicted person and a time limit is set for payment. If circumstances permit, the unpaid fine can be deducted from the convict's wealth or income instead".

Furthermore, Niniek Suparni stated that: "The definition of "if the circumstances permit" means that the convict is capable, but does not want to pay the fine. If such a substitute attempt is not possible, a substitute imprisonment shall be imposed on him. The provisions for the convicted person to pay his fine as much as possible must be interpreted that he is given the opportunity by the judge to pay the fine ". Judging from the opinion of Niniek Suparni, 
that the application of a fine which is an obligation for the convict to pay it, this can be applied to convicted of corruption.

\section{Research Methods}

The method used in this research is normative research or also known as literature law research is: "Legal research is carried out by examining library materials or mere secondary data". The data used in this study are secondary data, namely data whose sources are obtained from literature review and carried out by making an inventory of all regulations and data that are related to the object of research obtained from: primary legal materials, secondary legal materials and tertiary legal materials, namely materials that provide explanation of primary legal materials and secondary legal materials in the form of dictionaries and encyclopedias.

\section{Results and Discussion}

The development of special offenses in the community in the economic sector is closely related to what is known as "white collar crime" and "professional crime", which can generate large amounts of material benefits such as corruption. If the perpetrator is only subject to imprisonment, then he still has the possibility to enjoy the proceeds of the crime. In this case, the punishment can be used to pursue the wealth resulting from the criminal act of corruption committed by the convicted person.

Based on Law Number 20 of 2001 in conjunction with Law Number 31 of 1999 concerning Eradication of Corruption, the cumulative application of imprisonment and fines is applied. In its implementation, of course, it must be supported by the means to enforce the fine sentence imposed by the judge. Medan District Court Panel of Judges, decision Number $68 /$ Pid.Sus-TPK / 2017 / PN Mdn, November 14, 2017.

In the criminal case of corruption committed by the defendants which caused losses to the state finances cq. Regional Finance of Pakpak Bharat Regency, in this case the Pakpak Bharat Regency Government, is Rp. 471,945,000, - (four hundred and seventy one million nine hundred and forty five thousand rupiah), or at least the amount of Rp. 220,000,000, - (Two hundred and twenty million rupiah). Judges in their legal considerations refer to Article 2 paragraph (1) Jo. Article 18 paragraph (1) letter b, paragraph (2), paragraph (3) Law Number 31 of 1999 concerning Eradication of Corruption Crimes as amended and supplemented by Law Number 20 of 2001 concerning Amendments to Law Number 31 of 1999 concerning the Eradication of Corruption Crime. Imposing crimes against the Defendants: Sahitar Berutu, S. Ag. MA (Defendant I) - Drs. Daulat Merhukum Solin (Defendant II) - Sahrun Kudadiri, S.Pdl (Defendant III) - Ren Haney Manik, A.Md (Defendant IV) with imprisonment for 1 (one) year and 6 (six) months each and a fine. -Each IDR 50,000,000 (fifty million rupiahs) provided that if the fine is not paid, it must be replaced by imprisonment for 1 (one) month each.

In the application of such fines, juridically referring to Law Number 20 of 2001 in conjunction with Law Number 31 of 1999 concerning Eradication of Corruption, does not regulate the length of substitute imprisonment if the fine is not paid by the convict, either a person or a corporation. Therefore, the determination of the duration of the substitute imprisonment refers to Article 30 paragraph (4) of the Criminal Code, that: "In the judge's decision, the duration of the substitute imprisonment is stipulated thus; if the fine is seven 
rupiah and fifty-two cents or imprisonment, the count is one day; If it is more than five rupiahs and fifty cents, every seven rupiahs and fifty cents is counted at the most one day.”.

If you look at the provisions of Article 30 paragraph (4) of the Criminal Code mentioned above, even though it is multiplied by the currency value or the imprisonment calculated from a day, at this time it is no longer relevant, because imprisonment in lieu of fines is considered too light, when compared to a fine of Rp. 50,000,000, - (fifty million rupiah) in lieu of imprisonment for 1 (one) month. So it is possible that the convicts will undergo or choose to be imprisoned instead of having to pay a fine of Rp. 50,000,000, - .

Through the judge's view that is reflected in the decision, it can be concluded that judges based solely on positive law, in legislation always provide a formulation with imprisonment for unpaid fines. This is one of the causes of ineffective implementation of fines in judicial practice. Therefore, fines are rarely applied singly. Thus it can be said that no matter how high the fine imposed, if the convict is unable to pay, the consequence is only 1 (one) month imprisonment. In the event that the perpetrator of corruption commits a criminal act of corruption that can generate a lot of profit, the perpetrator can still enjoy the results without worrying that his property will be used to pay a fine because it can be replaced with a light imprisonment.

Efforts to tackle corruption through legislation and criminal law enforcement have actually been carried out for a long time. However, it must be admitted that corruption still exists and is difficult to eradicate. This is because corruption is related to various other complex problems such as problems with mental attitudes, morals, patterns or attitudes in social life, problems of economic needs or demands, economic structures or systems, cultural or political structures, problems of opportunities in development mechanisms and as well as weaknesses in bureaucracy or administrative procedures, including the financial system and public services. Given the complexity of the problem, the anti-corruption policy cannot be solved in a fragmentary way, but must be carried out in a comprehensive and integral manner. Structural and substantive approaches will not be successful if they are not followed by cultural and ethical approaches from the law enforcers themselves which are often contaminated with continued corruption. With the provision of high fines in the Corruption Crime Law, at least it contributes to reducing the incidence of corruption.

Because, by implication, the application of criminal penalties does not achieve the purpose of punishment, referring to the opinion of P.A.F Lamintang and Theo Lamintang, basically there are three main points of thought about the goals to be achieved with a punishment, namely:

a. To correct the personality of the criminal himself;

b. To make people deterred from committing crimes.

c. To make certain criminals incapable of committing another crime, that is, criminals who by other means are irreparable.

If you look at the objectives of letters $b$ and $c$ above, the application of imprisonment in lieu of fines does not fulfill the deterrent effect and may commit corruption again. If we look at the theory of objectives (relative theory and theory of improvement) the consequences of this punishment will result:

a. Prevention of a crime by making threats that are serious enough to frighten would-be criminals.

b. Correction or education for criminals to the community is given education in the form of crimes so that they can return to the community in a better and more useful mental state. There are three ways to improve criminals, namely: intellectual improvement, moral improvement and juridical improvement. 
c. Getting rid of criminals from the environment or social interactions, the way is for criminals who are immune to criminal threats in the form of an attempt to frighten them, so that they are sentenced to a sentence that will deprive them of their independence for quite a long time, even if necessary by the death penalty.

d. Ensuring public order is done by establishing norms that guarantee legal order to violators of these norms and the state can also impose penalties.

In the case that the imposition of a fine on a criminal act of corruption is a cumulative weighting of the crime. So the pattern of imposing the fine to be imposed needs to be considered, among others:

a. In imposing a fine, it must be considered the ability of the convicted person and the legal justice that governs it, in this case Law Number 20 of 2001 in conjunction with Law Number 31 of 1999 concerning Corruption Eradication.

b. In assessing the ability of a convicted person, it is mandatory to pay attention to the assets owned by the convicted person and his family, in this case the wife or husband of the convicted person, their children and possibly the closest relatives who are suspected of having the flow of corruption funds from the convicted person.

c. Determination of the convict's ability to consider the ability of the convicted person does not detract from the special minimum fines stipulated for certain crimes.

d. Fines can be paid in installments within a grace period in accordance with a judge's decision.

e. If the fines are not paid in full within the stipulated grace period, the unpaid fines can be taken from the convict's wealth or income.

f. If the taking of wealth or income is not possible, then a fine that is not paid is replaced by social work, supervisory or imprisonment where a sense of justice is fulfilled for the sake of the law and the provisions of the criminal fine do not exceed the category I fine.

g. Regarding the penalty in lieu of fines in the form of imprisonment which is applied it must be commensurate with the criminal fines in order to realize justice for the law.

h. The criminal penalty in the criminal act of corruption must be a criminal justice in terms of the imposition of punishment for the convicted of corruption.

i. Criminal fines must have a purpose regarding the return of state finances and the country's economy which is hampered by the actions of the convicted corruption.

For the sake of law enforcement and the realization of legal justice, the application of criminal fines must be carried out in a structured manner and there is intensive supervision, especially in relation to the flow of funds from the payment of the criminal fines, so that there are no irregularities in the state finances. If the pattern of the application of this fine is applied in every judge's decision in a corruption case, a sense of justice for the sake of the law will be fulfilled. In the theory of the law of justice, John Rawls explains that: "Justice is the main virtue in social institutions, as truth is in the system of thought. A theory, however elegant and economic, must be rejected or revised if it is not true, so laws and institutions, no matter how efficient and neat, must be reformed or abolished if they are unfair.".

So in the Corruption Eradication Law, it is necessary to have legal certainty. The decisionmaking officials regarding future fines related to the implementation of the criminal fines need to be considered, the system for determining the amount or amount of the criminal fines, the time limit for the execution of the criminal fines, coercive actions which are expected to guarantee the payment of fines in the event the convict is unable pay within a predetermined time limit, the implementation of fines in special cases, and guidelines or criteria for imposing criminal fines and there is reformulation related to penalties in lieu of fines that are more appropriate by taking the convict's assets from the proceeds of corruption, such as what is 
applied in additional penalties Article 18 of Law Number 31 Year 1999 concerning Eradication of Corruption Crime and if his assets are insufficient, the convict is obliged to pay in installments according to the assets he corrupted, so that the government's objective in recovering state financial losses can be the sense of justice is fulfilled and realized for the sake of the law means that the application of criminal fines is not only limited to sanctions stipulated by the Corruption Eradication Law and judges' decisions, but its implementation cannot be carried out effectively.

\section{Conclusion}

Corruption is an extra ordinary crime that damages the government structure and the image of the country in the eyes of the world as well as losses to state finances or the state economy and hinders national development, if there are many corruptors in the official circles. The imposition of criminal sanctions in criminal acts of corruption is felt to have not been effective and has not fulfilled the government's objectives in recovering state finances, because judges in imposing criminal sanctions have alternative subsidies for imprisonment that are considered too light, when compared to the fines charged by corruption convicts. . So the penalty in lieu of fines in the criminal act of curops has not yet fulfilled the government's objectives in recovering state financial losses and there is no tangible sense of justice for the law

\section{References}

[1] Faisal Santiago, Jurnal Pagaruyuang, Universitas Muhammadiyah Sumatera Barat, 2017.

[2] Lilik Mulyadi, Pembalikan Beban Pembuktian Tindak Pidana Korupsi, Bandung: Alumni, 2007, hal. 3.

[3] Romli Atmasastmita, Strategi dan Kebijakan Pemberantasan Korupsi Pasca Konversi PBB Menentang Korupsi Tahun 2003, Bandung: Alumni, 2006, hal. 1.

[4] Pengadilan Negeri Medan Putusan Nomor 68/Pid.Sus-TPK/2017/PN Mdn.

[5] Jur. Andi Hamzah, Pemberantasan Korupsi Melalui Hukum Pidana Nasional dan Internasional, Jakarta: Raja Grafindo Persada, 2012, hal. 4-6.

[6] Martiman Prodjohamidjojo, Penerapan Pembuktian Terbalik Dalam Delik Korupsi (UU No. 20 Tahun 2001), Bandung: Mandar Maju, 2009, hal. 8.

[7] Undang-Undang Nomor 31 Tahun 1999 tentang Pemberantasan Tindak Pidana Korupsi, Psal 2 ayat (1).

[8] Firman Wijaya, Peradilan Korupsi (Teori dan Praktik), Jakarta: Maharini Press, 2008, hal. 18.

[9] Undang-Undang Nomor 31 Tahun 1999, Op.cit., Pasal 3.

[10] Andi Hamzah, Korupsi di Indonesia: Masalah dan Pemecahannya, Jakarta: Gramedia Pustaka Utama, 2013, hal. 103.

[11] Firman Wijaya, Op.cit., hal. 21-22.

[12] Undang-Undang Nomor 17 Tahun 2003 tentang Keuangan Negara, Pasal 1.

[13] Undang-Undang Nomor 17 Tahun 2003 tentang Keuangan Negara, Pasal 1.

[14] Ibid., Pasal 4.

[15] Kitab Undang-Undang Hukum Pidana, Pasal 10. 
[16] Niniek Suparni, Eksistensi Pidana Denda Dalam Sistem Pidana dan Pemidanaan, Jakarta: Sinar Grafika, 2007, 36.

[17] Loc.cit.

[18] Soejono Soekanto, Pengantar Penelitian Hukum, Jakarta : Universitas Indonesia, 2014, hal. 52 .

[19] Kitab Undang-Undang Hukum Pidana, Pasal 30 ayat (4).

[20] P.A.F Lamintang dan Theo Lamintang, Hukum Penitensier Indonesia, Jakarta: Sinar Grafika, 2010, hal. 11.

[21] John Rawls, A Theory of Justice (Teori Keadilan) Dasar-dasar Filsafat Politik untuk Mewujudkan Kesejahteraan Sosial dalam Negara, Yogyakarta: Pustaka Pelajar, 2019, hal. 3-4. 